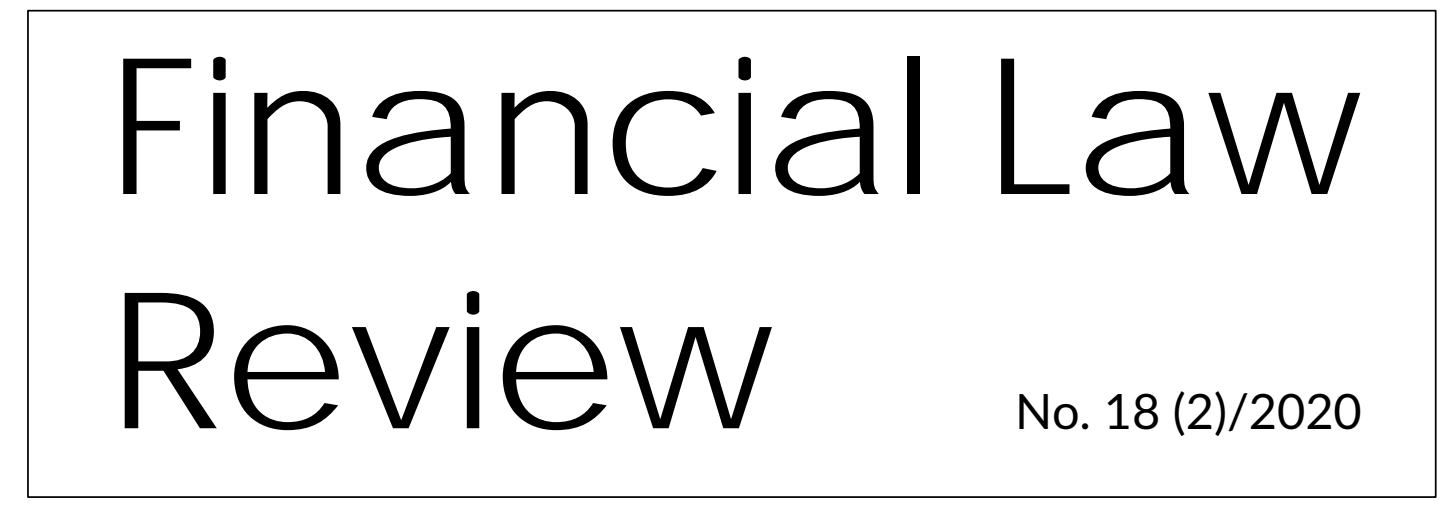

UNIVERSITY OF GDAŃSK • MASARYK UNIVERSITY • PAVEL JOZEF ŠAFÁRIK UNIVERSITY • UNIVERSITY OF VORONEZH http://www.ejournals.eu/FLR

\title{
ROMAN SMELIK* \\ ECONOMIC SECURITY OF THE ORGANISATION: FINANCIAL COMPONENT MANAGEMENT
}

\begin{abstract}
This contribution deals with the financial component that is a key structural element in the system of economic security. The aim of this article is to identify the counterparties of the external environment and certain elements of the internal environment as the main directions in ensuring the financial security of an enterprise. The extraction of the external partners is aimed at identifying potential threats in the financial sphere from the unfair actions of contractors, customers, resource suppliers, buyers of finished products. The work on financial security within the enterprise itself is aimed at determining and systematically monitoring of the level of financial stability, financial independence and solvency of the enterprise itself. Both areas of this work should be carried out in an integrated and systematic manner. In the process of achieving the aim several popular and formal scientific methods were used, such as a dialectical method of knowledge, as well as the logical, systemic, historical and formally legal method. Accordingly, there are also the main stages of financial security work: the document phase; the property management phase; the reporting phase; the phase of monitoring of indicators. The essence and content of each of these phases are described in the article.
\end{abstract}

Key words: economic security, financial security, inventory, reporting; financial security indicators

JEL Classification: G1, G10

${ }^{*}$ Professor for economics, head of the department of business management and economic security at FSBEI HE Dostoevsky Omsk State University, economics faculty, Dostoevsky Omsk State University, Russia. Author specializes in economic security. He is the author of 4 books and more than 30 reviewed articles in prestigious journals. Contact email: SmelikRG@omsu.ru. 


\section{Introduction}

The development of the market economy in Russia faces inevitable problems of the economic security of business and entrepreneurship. The experience of economically developed countries makes it possible to conclude that the basis of the system of the economic security of business is the state of the protection of vital interests of business entities and objects. At the same time, subjects and objects are both natural persons or individual entrepreneurs, as well as legal entities or organizations of various forms of ownership. In general terms, potential threats to economic security for business can be:

- unlawful acts against property,

- unfair competition,

- unlawful actions by criminal structures,

- fraud between business entities,

- corruption and bribery,

- instability of operation of economic entities,

- non-compliance with contractual obligations.

Considering the above, it can be concluded that the economic security of the business at the enterprise level is significantly influenced by the state of legal and economic relations, organizational ties, material and intellectual resources of the enterprise, in which the stability of its functioning, financial stability, commercial success, effective scientific and technical development are guaranteed.

The economic security of an enterprise in modern conditions is interpreted differently by different experts. In our view, the most functional definition is the following.

An enterprise's economic security is a state of the efficient use of resources to prevent challenges and threats and ensure its sustainable functioning.

It is clear that the economic security of an enterprise is based on the efficient operation of the service of the enterprise that can prevent security challenges and threats. If challenges and threats are not fully averted, then economic security must effectively address the damage and minimize the negative consequences. The sources of challenges and threats to economic security may be informed or unconscious actions of people, organizations, state authorities, international organizations, rival enterprises.

In addition, such sources of challenges and threats can be various combinations of the circumstances: the state of financial conditions in the markets of this enterprise, the state 
of payment capacity of consumers, scientific discoveries, technological developments, force majeure circumstances, etc.

\section{Adverse Impacts on the Economic Security of an Enterprise}

Negative impacts on the economic security of the enterprise can be classified into two types:

- objective negative impacts. They occur without the participation or beyond the will of the enterprise or its employees;

- subjective negative effects. They are the result of an effective operation of the enterprise as a whole or its individual employees.

In addition, during the assessment of economic security of an enterprise, it is advisable to take into account the risks of specific types of business activities: industrial entrepreneurship, commercial entrepreneurship, consulting entrepreneurship, financial entrepreneurship, etc.

The practical experience shows that there are more challenges and threats to economic security in a business where the profit rate is higher.

\subsection{Organizational Assets}

To ensure economic security, an enterprise must effectively use its organizational assets.

The organizational assets are business factors used by business owners and managers to achieve business goals. From the economic security perspective, the most important types of organizational assets are:

1) Capital resource. The share capital of the enterprise, combined with the loan financial resources, is the blood system of the enterprise and allows to acquire and maintain the remaining corporate resources, which are not initially available to the creators of the enterprise.

2) Human Resource. Managers of the enterprise, engineering staff, production workers and employees with their knowledge, experience and skills are the linking that connects all the factors of the business, ensuring implementation of business ideology, as well as achievement of business goals. 
3) Resource of information and technology. The information relating to all aspects of an enterprise is currently the most valuable and costly of the enterprise's resources. It is the information about the changes in the political, social, economic and environmental situation, the markets of the enterprise, scientific, technical and technological information, specific know-how concerning any aspects of the business, innovations in the methods of organization and management of business allow the enterprise to adequately respond to any changes in the external environment of the business, effectively plan and carry out its economic activities.

4) Resource of equipment and materials. Based on available financial, information technology and human resources capabilities, the enterprise acquires the technological and other equipment which, based on the available resources and according to the managers of the enterprise, is both necessary and accessible. The availability of modern technology and equipment is an inevitable factor of success. The economic security requires regular replacement of the obsolete equipment with new generation equipment. It is important to remember that obsolescence of machines and wear of equipment in the conditions of the innovative economy appears within 4-6 years. This period is significantly less than the physical wear. The effective system of the economic security of the enterprise inevitably pushes the management to constantly answer the main question, whether a greater risk is to use the available equipment until full physical wear or to replace it ahead of schedule with an innovative, modern and more efficient equipment?

5) The rights resource. This resource includes the right to property and property of the enterprise, the right to use patents of inventions and technologies, the right to use trademarks and brand names, licenses for specific activities, quotas for the use of natural resources (including land), quotas for the production of export products and public order products. From the point of view of economic security, the special role of this resource is due to the constant increase in the value of intangible assets of the enterprise. The efficient use of the resources of the law makes it possible to ensure a high level of economic security.

The main objective of the economic security of an enterprise is to ensure its sustainable and maximum effective functioning and to ensure the high potential for the development and growth of the enterprise in the future. Efficient use of corporate resources of the enterprise is achieved by preventing threats of negative effects on the economic security of the enterprise. 
In order to apply the modern management methods, the existence of the main goal of economic security implies its division into a number of sub-goals of a smaller scale. Such sub-goals are called functional objectives of economic security of the enterprise. They are:

- ensuring the high financial efficiency of the enterprise and its financial sustainability and independence;

- ensuring technological independence of the enterprise and achieving high competitiveness of its technological potential;

- achieving high efficiency of the enterprise management, optimality and efficiency of its organizational structure;

- ensuring a high level of skills of the company personnel, using its intellectual potential

- achieving a high level of the environmental friendliness of the enterprise, minimising the destructive impact of the results of production activities on the state of the environment;

- ensuring quality legal protection of all aspects of the enterprise's activity;

- ensuring the protection of the information environment of the enterprise, trade secrets and achieving a high level of information support for the work of all its services;

- ensuring the physical security of the personnel of the enterprise, their capital, property and commercial interests.

The achievement of each of the above functional objectives of the economic security of the enterprise is essential for the achievement of its main objective as well. In addition, each of the functional objectives has its own sub-goal structure, conditioned by the functional expediency and nature of the operation of the enterprise.

Considering the above the economic security of an enterprise must be seen as a process of achieving functional objectives, with the primary objective of preventing challenges and threats to economic security on specific fronts.

The main content of the operation of the economic security system of the enterprise at the tactical or current level is to develop a response to the emerging real threat to economic security. The main steps at this level are:

- assessment of the negative impact of a real threat to economic security;

- development of scenarios on the effects of adverse effects;

- damage assessment for different options of negative impact scenarios; 
- analysis of enterprise capabilities and resources according to different scenarios of negative impact;

- development of enterprise response to different versions of negative impact scenarios;

- choosing the most effective and optimal response to negative impacts.

The time of the operation of the economic security system of the enterprise at the tactical level depends on the size of the enterprise. If the enterprise is small, the time is short. If the enterprise is big, the time is longer. However, experts believe that the tactical level of the operation of the economic security system of the enterprise should not exceed one year.

The longer period of the operation of the economic security system is considered at a strategic or the promising level, it lasts from one year to three years. In large enterprises, this period may be increased. The main content of the work at this stage consists in strategic forecasting of promising markets for products, raw materials and materials, the impact of the state on the economy, prospects for the development of technology and technology, prospects for the emergence of potential competitors, state policy in the field of the labour market and social relations, prospects for the development of the foreign partnership, etc.

The economic security of the business at the enterprise level is significantly influenced by the state of legal and economic relations, organizational ties, material and intellectual resources of the enterprise, in which the stability of its functioning, financial stability, commercial success, effective scientific and technical development are guaranteed. The economic security of an enterprise is based on how effectively the services of that enterprise are able to prevent security challenges and threats. Ensuring the economic security of an enterprise must be seen as a process of achieving functional objectives, with the primary objective of preventing challenges and threats to economic security in specific directions.

To date, there is no common interpretation among experts in the field of economic security of the essence of the financial component of the economic security of the organization. There are various approaches. Some authors identify financial security with the state of solvency and financial sustainability. Other authors reduce financial security to the level of the business activity of the enterprise and the level of profitability. There are 
scientific approaches that equate financial security with the level of financial independence.

In our opinion, the most complete definition of the financial component of the economic security of the enterprise is as follows.

Enterprise financial security is the ability of an enterprise to independently develop and implement a financial strategy in accordance with the objectives of an overall corporate strategy in an uncertain and competitive environment.

The main condition for the financial security of an enterprise is the ability to withstand existing and emerging dangers and threats that seek to cause financial damage to the enterprise or/and it is desirable to change the structure of the capital, or to forcibly eliminate the enterprise. To ensure this condition, an enterprise must maintain financial sustainability, balance, ensure sufficient financial independence of the enterprise and flexibility in financial decision-making.

\section{Financial Security Phases}

It is the author's opinion that the main efforts to ensure the financial security of the enterprise can be divided into two directions (Table 1).

Table 1. Directions for the ensuring of financial security

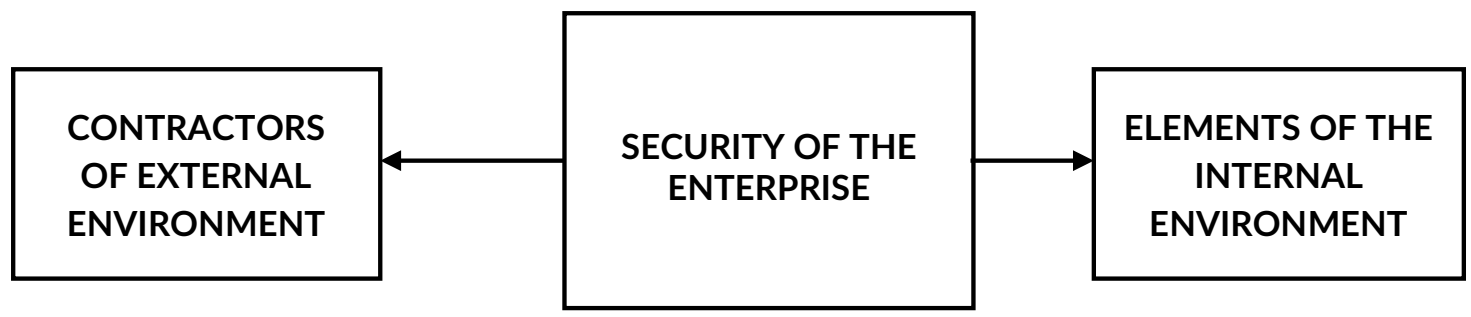

Source: Author's own elaboration.

Working with external partners is aimed at identifying potential threats in the financial sphere from unfair actions of contractors, customers, resource suppliers, buyers of finished products, etc.

The work on the financial security within the enterprise itself is aimed at the determining and systematically monitoring of the level of financial stability, financial independence and solvency of the enterprise itself. 
Both external and internal work should be carried out in a systematic and integrated manner. This is due to the close mutual relationship between one direction and another. For example, financial failures in dealing with suppliers will inevitably lead to a deterioration in financial security within the enterprise itself. On this basis, the main stages of financial security work can be considered as the following (Table 2) [Smelik 2016: 6768].

Table 2. Financial security phases

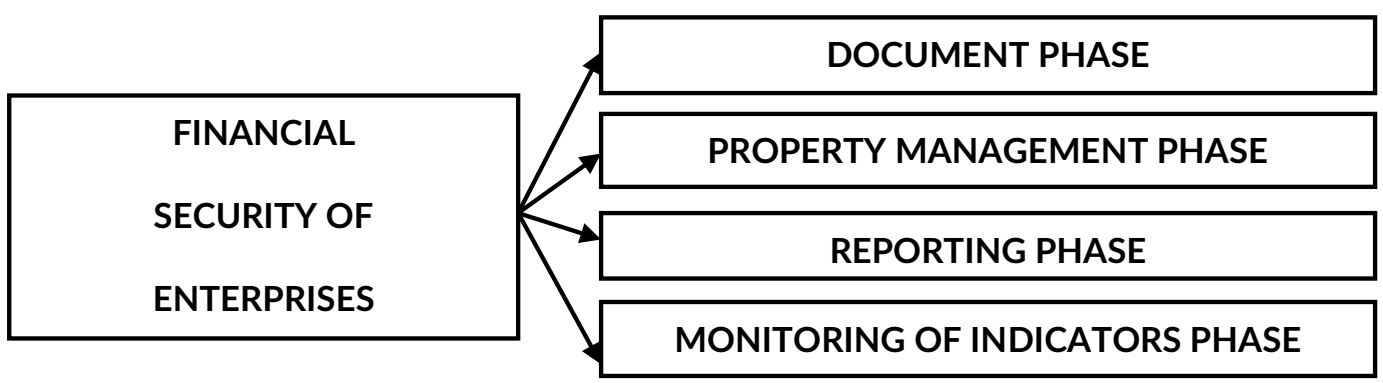

Source: Author's own elaboration.

\subsection{Document Phase}

The main purpose of the work at this stage is to familiarize with the primary financial documents, determine their authenticity, identify the presence of errors, determine the nature of errors (accidental or intentional), predict the use of such documents in business transactions.

In accordance with the current legislation, from 2013 to the present, any enterprise and organization independently decides which financial documents to issue for a business transaction. Today enterprises use electronic computer programs in which the forms of the financial documents are unified. Such programs include the family of programs "1C," BEST, "PRO," PARUS" etc. However, regardless of which software product the enterprise uses, the forms of financial documents must be approved by the head of the enterprise. With regard to the view of financial security, it is necessary to know and understand the following with regard to documents.

The original financial document must have mandatory details. These details must be filled in. Details can be entered in advance, in which case the document is presented as a standard form. All clean fields are filled in the form. The props, which cannot be filled in, 
are drawn by a stroke. The details in the form can be filled with a ball or helium pen, ink or using a computer. You cannot use a pencil as well as a rod that can "distort" information over time. Grammatical and spelling errors are not allowed when filling in the form. Information containing monetary amounts is indicated in numbers and words. Financial documents, in accordance with the current regulatory requirements, contain mandatory data:

- name of the document;

- date of compilation of the document;

- name of the organization that compiled the document;

- content of the fact of business life (i.e. business transaction);

- value of natural and/or monetary meter with the indication of units of measurement (can be either monetary indicators or natural, or both);

- name of the official who performed the transaction and is responsible for the correctness of the registration (these may be different persons: one gives permission for the operation, the other performs, and both sign the document);

- signatures of these persons with their names and initials (this is necessary for identification of these persons, i.e. signatures, names and initials must be legible).

Looking at the economic security, it is necessary to check all the above-mentioned details. If the content of the completed details is doubtful during the verification, such a document should be re-checked. Then, the financial document is corrected by the employee of the enterprise to whom the manager instructed to carry out the business transaction. The list of persons entitled to carry out business operations must be approved by the order of the head of the enterprise. Thus, the right to carry out business transactions is assigned to specific persons.

Financial documents of the enterprise should have a limited range of access. They should be worked with only those performers who need it for the quality of their duties. Individual financial documents may constitute the subject of trade secrets of the organization. Authorities with the right of access to internal financial information of enterprises must submit special permits. Such organizations include the Federal Tax Service, the Departments for Combating Economic Crimes of the Ministry of Internal Affairs of the Russian Federation, the prosecutor's office, etc.

Meeting the challenge of the financial security requires the ability to verify financial documents - check the correctness of the data, required signatures, legibility or arithmetic 
check of correct calculation of monetary amounts specified in the document. The legality and expediency of the business transaction shall be checked. In addition, during the check, you must make sure that the business transaction has actually been carried out or in the specified scope (bogus check). If minor errors are detected during the check of the financial document, which do not affect the monetary amounts (incorrect units of measure, signature without decryption of the surname, errors in the text, etc.), they must be corrected. In this case, a proofreading method is applied: the misspelt word is crossed out by a thin line so that it can still be read, then the correct text is written next to it with a specific annotation: "a correction was made due to an error", then the date and signature of the person who made the correction is marked. The correction must be made by the performer. If it is impossible to correct the error by the contractor - the correction can be made by a specialist appointed by the manager [Karanina 2016: 132].

If errors affecting monetary amounts are detected in the verification of financial documents, they shall not be corrected. Such a document is cancelled, and a new one is issued instead.

\subsection{Property Management Phase}

The main purpose of the work at this stage is to actually verify the property at the disposal of the enterprise, to identify the facts and causes of the loss of property or the loss of property. From the point of view of the financial security of an enterprise, the main content of this stage is the inventory [Smelik 2015: 135 - 142].

The term "inventory check" is of Latin origin. In the ancient world, the concept of "inventarium" meant "a list of what is found." The essence of the ancient inventory was the arithmetic calculation of the available property. The result of this calculation was a kind of table, listing the types of property and their quantity. Such a document later became known as an inventory. In the modern sense, the essence of the inventory is much more complicated. The basis of the inventory is the principle that for each property a particular employee of an enterprise must be responsible. Such an employee, in accordance with normative documents, is called an accountable officer who is appointed at the moment of coming into possession of a property and is responsible for correct operations. The person is also responsible for the proper disposal of property. The list of accountable officers is approved by an order of the head of the enterprise. The necessary training and instruction are provided to the responsible persons. 
Looking at the economic security, it is important to understand that any property in the organization must exist simultaneously in two forms: first, it is a property that is available to the enterprise, it is used in daily activities, and it is the responsibility of an accountable officer. Second, the same property should be recorded on financial accounting. On the basis of the received documents, the property is taken into account in the accounting department, it becomes the balance sheet property of the enterprise, and the employee of the accounting department is responsible for it. In such a case, from the point of view of economic security, it is necessary to find out whether what is available is the same as what is recorded. Thus, the essence of the inventory is to check the actual existence of the property and its compliance with the financial accounting data in the enterprise.

The main normative document regulating inventory is called "methodical instructions on the inventory of property and financial obligations", the approved order of the Ministry of Finance of the Russian Federation of 13.06.1995 no. 49. This document describes the entire physical inventory procedure and describes the forms of documents used in the physical inventory.

There is an inventory that includes all assets and liabilities. Such inventory is called a complete inventory. An inventory that covers one or more assets and liabilities (e.g. materials, cash, fixed assets) is called a partial inventory.

The inventory may be planned or unplanned - carried out at any time depending on the needs. The sources of the decision to carry out the inventory may be: the management of the enterprise, the owners of the enterprise or the control bodies. Such an inventory is called proactive.

There are situations where it is mandatory to carry out an inventory. Such cases include:

- a transfer of property for rent, ransom, sale;

- change of material and responsible persons (dismissal, illness, etc.);

- detection of theft, abuse or damage to property;

- natural disasters, fires and other emergencies;

- financial year reporting.

Inventory check of the enterprise can be counted once every three years, other property is to be counted annually.

The inventory is carried out in several stages. At the preparatory stage, the relevant order of the head is issued and an inventory commission is appointed, the commission is briefed, 
the accountable officer prepares the property for inspection, all receipts and expenditure documents are processed, technical means (scales, meters, etc.) are prepared.

The executive stage is the direct work of the Property Survey Commission at the site. At the same time, the commission uses counting, measurement and weighing. The Property Survey Board can only conduct an inventory in full, the absence of at least one member of the Board invalidates the results. The presence of an accountable officer is mandatory, without whom the results are also invalid. The results of the commission's work on the site are recorded in special inventory records. All inventory records are signed by the commission and the accountable officer.

At the final stage, all inventory records are handed over to the accounting department. In case of revealing any inventory divergences, the collation sheets are formed. For each instance of a discrepancy, the commission determines the reasons and accountable officer prepares a written explanation. Then, the final document - the inventory report - is drawn up. The act is signed by all members of the commission. The certificate reflects the reasons for discrepancies between the records and availability and makes proposals to eliminate the identified shortcomings. If the actual data is greater than the accounting data, it is a surplus. The surplus should be capitalized as the property of the enterprise. If the actual data is less than the accounting data, then the shortfall must be recovered. The compensation for the shortfall is made at the expense of the perpetrators (if established) usually the accountable officer or the costs are borne by the enterprise itself if the perpetrators are not identified. Both assets recognition (surplus) and coverage of the shortfall is carried out based on a written order of the head of the enterprise. The basis for such an order is an inventory act. Thus, the inventory as a means of ensuring the economic security of the enterprise begins with the order of the manager and ends with the order of the head of the enterprise.

\subsection{Reporting Phase}

From the perspective of financial security, it is necessary to be able to work with official documents that contain complete, reliable and transparent information about the business activities of the enterprise. At the same time, it is not quite important whether it is a counterparty or one's own enterprise. In accordance with the regulatory requirements, the purpose of financial reporting is to provide the necessary information to all interested users. Thus, financial reporting is simply a set of documents that contains business 
information that users need. From a financial security perspective, the reporting information structure is as follows (Table 3).

Table 3. Structure of information of the reporting



Source: Author's own elaboration.

A specialist in the field of economic security, having read financial statements, should be able to draw a preliminary conclusion on the financial situation of the enterprise in question, on the financial result and its structure, and the directions of flow of funds.

Financial statements based on the results of an enterprise operation for the financial year are mandatory. In addition, if necessary, enterprises can make not only annual reports but also interim ones, for less than 1 year. Such periods can be a month, a quarter, 6 or 9 months.

Yearly financial statements include:

- balance sheet;

- statement of financial results (profit and loss);

- applications;

- capital change report, which contains information on the size and changes in equity and equity financing;

- cash flow report, which contains information on balances, income and expenditure of funds; 
- explanations to the balance sheet, revealing and detailing the information contained in the balance sheet;

- an explanatory note to the annual financial report, which reveals information about the property and financial situation;

- report on the average number of employees;

- audit report confirming the validity of financial statements.

Despite a significant number of applications with detailed information, the main forms of financial reporting are the balance sheet and financial results report.

\subsection{Monitoring of Indicators Phase}

The content of this stage is limited to the calculation of economic indicators characterizing the state of the financial component of the economic security of the enterprise. The list of these indicators, the method of their calculation, the frequency of their determination are established by the management of the economic entity. On the basis of the practice of the economic security divisions of Russian enterprises, the most often calculated are indicators determining the level of financial independence of the enterprise, financial stability of the enterprise, as well as indicators characterizing the level of security of certain types of working capital.

\section{Conclusion}

The business and enterprise economic security plays an important role in the development of the market economy. The investigated financial components of the economic security of an enterprise, as basic structural elements of this system, have two directions. The first direction is external, related to the analysis of challenges and threats to the economic security of the external environment, and the second direction is internal, related to threats to economic security coming from the state of the internal environment of the organization.

It is also necessary to take the four stages of work into account to ensure the financial security of the organization. The first stage is the work with documents; its main purpose is to determine the authenticity of documents and to identify the presence of accidental or intentional errors. The second stage is property management. This phase is aimed at 
verifying the property at the disposal of the enterprise, i.e. the inventory. The third stage is the work with financial reporting to provide the necessary information to all interested users. The fourth stage is monitoring, i.e. calculation of economic indicators characterizing the state of the financial component of the economic security of the enterprise.

Based on a detailed analysis of the content of these stages, it was concluded that the financial component is one of the key structural elements in the economic security system of an enterprise. Therefore, it is obvious that the stability of the enterprise, its financial stability, commercial success, effective scientific and technological development depend on the state of legal and economic relations, organizational ties, material and intellectual resources of the enterprise. The economic security of an enterprise also depends directly on the efficient use of corporate resources that are used to achieve the business goal.

Ensuring sustainable and maximum effective functioning and potential of enterprise development and growth is impossible without prevention of challenges and threats to economic security in specific directions and ability to cope with existing and emerging dangers. The implementation of these actions in the process of carrying out economic activities by the organization, which are a set of methods, is necessary to ensure the power safety of the organization.

\section{References:}

Karanina E.V.: Finansovaja bezopasnost' [Financial security. Monograph], Kirov: Vjatskij Gosudarstvennyj Universitet, 2016.

Smelik R.G.: Buhgalterskij uchjot i audit: Universitet Gil'el'mo Markoni, Italija, Rim [Accounting and auditing: Rome, Italy, Guilelmo Marconi University], Omsk: Izdatel'stvo OmGU [Publishing house of OmSU], 2016.

Smelik R.G.: Buhgalterskij uchet [Accounting: textbook], Publishing house of OmSU, 2015.

Goncharenko, L.P.: Jekonomicheskaja bezopasnost' [Economic security], Moscow: Izdatel'stvo Jurajt [Jurajt Publishing House], 2018.

Blazhevich, O.G.: Finansovaja bezopasnost' predprijatij: opredelenie minimal'no neobhodimogo urovnja [Financial security of enterprises: definition of minimum required level], Nauchnyj vestnik: finansy, banki, investicii [Scientific bulletin: finance, banks, investments], No. 3 [8], 2010.

Kazakova N.A.,: Jeffektivnost' biznesa. Finansovaja bezopasnost' kompanii: analiticheskij aspekt [Efficiency of business. Financial security of the company: analytical aspect], Available at: file:///C:/Users/Admin/Downloads/finansovaya-bezopasnost-kompanii-analiticheskiyaspekt\%20[1].pdf, accessed: 29.04.2020.

Kozlova A., Jekonomicheskaja bezopasnost' kak javlenie $\mathrm{i}$ ponjatie [Economic security as a phenomenon and concept], Vlast' [Power], No. 1, 2015. 
Shvaiba, D., Structural Stability and Socio-Economic Security of the Hierarchical System [June 18, 2018]. Available at SSRN: https://ssrn.com/abstract $=3197995$ or http://dx.doi.org/10.2139/ssrn.3197995, accessed 5th May 2020.

Endovickaja A.V., Volkova T.A., Baliashvili D.U.: Teoretiko-metodologicheskie podhody $\mathrm{k}$ opredeleniju sushhnosti jekonomicheskoj bezopasnosti predprijatija i ee ocenke [Theoretical and methodological approaches to the determining of the essence of economic security of an enterprise and its assessment], Sovremennaja jekonomika: problemy i reshenija [Modern economics: problems and solutions], No. 10, 2014.

Reddy, B., Evans, D.: Government Preferences for Promoting Open-Source Software: A Solution in Search of a Problem [May 21, 2002]. Available at SSRN: https://ssrn.com/abstract $=313202$ or http://dx.doi.org/10.2139/ssrn.313202, accessed: 29th April 2020.

Cetindamar D., Kilitcioglu H.: Measuring the Competitiveness of a Firm for an Award System. Competitiveness Review: An International Business Journal, vol. 23, 2013.

Zaporozhceva, L. A., Rjabyh M. A.: Razrabotka strategii obespechenija finansovoj bezopasnosti predprijatija [Development of a financial security strategy for the enterprise], Fundamental'nye issledovanija [Basic research], No. 11 [8], Penza, 2013.

Kolesnikova E. N.: Jekonomicheskaja bezopasnost': jekonomika i bezopasnost'? [Economic Security: Economics and Security?] , Juridicheskaja nauka i praktika, Vestnik Nizhegorodskoj akademii MVD Rossii [Legal Science and Practice. - Journal of the Nizhny Novgorod Academy of the Ministry of Internal Affairs of Russia], No. 21, 2016.

\section{Internet Resources:}

Uproshhjonka: Pravitel'stvo opublikovalo antikrizisnye mery dlja biznesa [Uproshhjonka: The government has published anti-crisis measures for business], Available at: https://www.262.ru/news/356188-pravitelstvo-opublikovalo-antikrizisnye-mery-dlya-biznesa, accessed: 20th March 2020.

\section{Legal Acts:}

Act of 6 December, 2011, No. 402 FL "On Accounting" (as amended in 2018). 